\title{
Anaplastic Thyroid Carcinoma with Humoral Hypercalcemia of Malignancy (HHM): An Autopsy Case Report
}

\author{
HIROSHI IWAI, YASUHIRO OHNO AND NORIHIKO AOKI \\ Department of Endocrinology, Metabolism and Diabetes, Kinki University School of Medicine, Osaka-Sayama 589-8511, Japan
}

\begin{abstract}
An 84-year-old woman was admitted to our hospital for the examination and treatment of painful right thyroid swelling on August 2, 2002. Thyroid ultrasonography showed a mass of about $6 \mathrm{~cm}$ in diameter at the right thyroid lobe. Aspiration biopsy cytology (ABC) of her mass showed a thyroid carcinoma. Her neck mass was cold on ${ }^{123}$ I scintigraphy and hot on both early- and delayed- phase ${ }^{201} \mathrm{Tl}$ scintigraphy. Whole body ${ }^{67} \mathrm{Ga}$ scintigraphy scan showed a strong hot accumulation in the area from the right thyroid lobe to the right lateral lobe. Multiple lung tumors were observed from chest computed tomography (CT) scans. She was diagnosed as having an anaplastic thyroid carcinoma with metastatic lung tumors. As her thyroid carcinoma was inoperable, percutaneous injection therapy of lipiodol and ethanol (lip-PEIT) against the primary thyroid carcinoma was performed twice a week. However, the thyroid carcinoma gradually enlarged and oppressed her trachea. Two months after the initiation of lip-PEIT, parathyroid hormone-related protein (PTHrP)dependent hypercalcemia was diagnosed because serum levels of calcium, phosphate and intact-PTHrP were $2.72 \mathrm{mmol} / 1$ $(10.9 \mathrm{mg} / \mathrm{dl}), 0.71 \mathrm{mmol} / \mathrm{l}(2.2 \mathrm{mg} / \mathrm{dl}), 3.2 \mathrm{pmol} / \mathrm{l}$, respectively. The hypercalcemia was reduced by the use of pamidronate. After one week she died of an airway obstruction caused by the developing thyroid carcinoma. Carcinoma cells with a mixed papillary and squamoid pattern were positively stained immunohistochemically by anti-PTHrP(1-34) antisera. Herein, we report a rare autopsy case of a PTHrP-producing thyroid carcinoma.
\end{abstract}

Key words: Thyroid carcinoma, HHM, PTHrP, Lip-PEIT

(Endocrine Journal 51: 303-310, 2004)

HYPERCALCEMIA in malignancy usually has a rapid onset and can cause confusion, stupor, nausea, vomiting, and dehydration. The incidence of hypercalcemia in malignancy is 15 cases per 100,000 personyears [1]. Malignancy-associated hypercalcemia is classified into two groups: one is humoral hypercalcemia of malignancy (HHM), which is induced by humoral factors, and the other is local osteolytic hypercalcemia (LOH), which is induced by cytokines such as interleukin- $1 \alpha$ (IL-1 $\alpha)$, IL-6, tumor necrosis factor- $\alpha$ $(\mathrm{TNF}-\alpha)$, and transforming growth factor- $\alpha(\mathrm{TGF}-\alpha)$ $[1,2]$. In the former, parathyroid hormone-related peptides (PTHrP) are purified from a squamous cell

Received: October 27, 2003

Accepted: February 18, 2004

Correspondence to: Dr. Hiroshi IWAI, Department of Endocrinology, Metabolism and Diabetes, Kinki University School of Medicine, 377-2, Ohno-Higashi, Osaka-Sayama, Osaka 589-8511, Japan carcinoma cell line and are measurable in the serum of patients with various malignancies including renal cell carcinomas, adult T-cell leukemia/lymphoma, multiple myeloma, B cell lymphoma, breast carcinoma, etc. [3, 4].

Anaplastic thyroid carcinoma constitutes about $1.6 \%$ of all thyroid carcinomas, usually occurs after the age of 60 years, and is approximately two times more common in women than in men [5]. This carcinoma is highly malignant, nonencapsulated, extends widely, and has a poor prognosis [6-11]. In several anaplastic thyroid carcinoma cell lines, many cytokines such as granulocyte-colony stimulating factor (G-CSF), granulocyte macrophage-colony stimulating factor (GMCSF), IL-1 $\alpha$, IL-6, and TGF- $\alpha$ are produced [12-15]. However, only four cases, including the present one, with a PTHrP-producing thyroid carcinoma have ever been reported to the best of our knowledge $[15,16]$. Here, we report a rare autopsy case of a patient with anaplastic thyroid carcinoma with HHM. 


\section{Case report}

An 84-year-old woman entered our hospital complaining of a painful right thyroid swelling in July, 2002. For examination and treatment of the swelling, she was admitted to our hospital on August 2, 2002. She had apoplexy at the age of 70 and a right femoral neck fracture at the age of 84 . Her physical examinations were as follows: height $147.4 \mathrm{~cm}$, body weight $41.3 \mathrm{~kg}$, body temperature $36.2^{\circ} \mathrm{C}$, blood pressure 138/ $72 \mathrm{mmHg}$, and pulse rate $78 /$ minute. There were no abnormal findings on her heart, lungs or abdomen. A large and painful mass from the right thyroid lobe to the lateral neck and right cervical lymph node swelling were palpable. Laboratory data showed mild anemia and a slight elevation of CRP and thyroglobulin (Tg) (Table 1).

Thyroid ultrasonography showed a low echoic mass of $60.6 \times 37.3 \times 26.3 \mathrm{~mm}^{3}$ in the right thyroid lobe and bilateral cervical lymph node swellings (Fig. 1). Aspiration biopsy cytology (ABC) of her mass showed Papanicolaou V, which was suspected as being a thyroid papillary carcinoma because of its intranuclear cytoplasmic inclusion.

Her neck mass on T1- and T2-weighted magnetic resonance (MR) images showed low- and high-intensity,

Table 1. Laboratory data on admission

\begin{tabular}{llllll}
\hline WBC & $5200 / \mu \mathrm{l}$ & $\mathrm{BUN}$ & $18 \mathrm{mg} / \mathrm{dl}$ & $\mathrm{TSH}$ & $2.4 \mu \mathrm{IU} / \mathrm{ml}$ \\
$\mathrm{RBC}$ & $371 \times 10^{4} / \mu \mathrm{l}$ & $\mathrm{Cr}$ & $0.8 \mathrm{mg} / \mathrm{dl}$ & $\mathrm{T} 3$ & $125 \mathrm{ng} / \mathrm{dl}$ \\
$\mathrm{Hb}$ & $11.7 \mathrm{~g} / \mathrm{dl}$ & & & $\mathrm{T} 4$ & $10.6 \mu \mathrm{g} / \mathrm{dl}$ \\
$\mathrm{Ht}$ & $35.6 \%$ & $\mathrm{TP}$ & $6.8 \mathrm{~g} / \mathrm{dl}$ & $\mathrm{Tg}$ & $249 \mathrm{ng} / \mathrm{dl}(<30)^{*}$ \\
$\mathrm{Plt}$ & $18.4 \times 10^{4} / \mu \mathrm{l}$ & Albumin & $4.2 \mathrm{~g} / \mathrm{dl}$ & & \\
& & & & $\mathrm{TGPA}$ & $10>$ \\
$\mathrm{CRP}$ & $1.2 \mathrm{mg} / \mathrm{dl}$ & T.Bil & $0.4 \mathrm{mg} / \mathrm{dl}$ & $\mathrm{MCPA}$ & $10>$ \\
$\mathrm{ESR}$ & $70 \mathrm{~mm} / \mathrm{hr}$ & GOT & $15 \mathrm{IU} / \mathrm{l}$ & & \\
& & GPT & $8 \mathrm{IU} / \mathrm{l}$ & & \\
$\mathrm{BS}$ & $106 \mathrm{mg} / \mathrm{dl}$ & Alp & $327 \mathrm{IU} / 1$ & & \\
$\mathrm{Na}$ & $143 \mathrm{mEq} / \mathrm{l}$ & Amy & $66 \mathrm{IU} / \mathrm{l}$ & & \\
$\mathrm{K}$ & $3.7 \mathrm{mEq} / 1$ & LDH & $184 \mathrm{IU} / \mathrm{l}$ & & \\
$\mathrm{Cl}$ & $103 \mathrm{mEq} / \mathrm{l}$ & & & & \\
$\mathrm{Ca}$ & $2.47 \mathrm{mmol} / \mathrm{l}(2.20-2.62)^{*}$ & T-cho & $208 \mathrm{mg} / \mathrm{dl}$ & & \\
$\mathrm{Pi}$ & $1.1 \mathrm{mmol} / \mathrm{l}(0.81-1.45)$ & Trig & $66 \mathrm{mg} / \mathrm{dl}$ & & \\
\hline
\end{tabular}

Abbreviations: Tg, thyroglobulin; TGPA, anti-thyroglobulin particle agglutination; MCPA, anti-thyroid microsomal particle agglutination.

* Numbers in parentheses indicate the normal range.

A

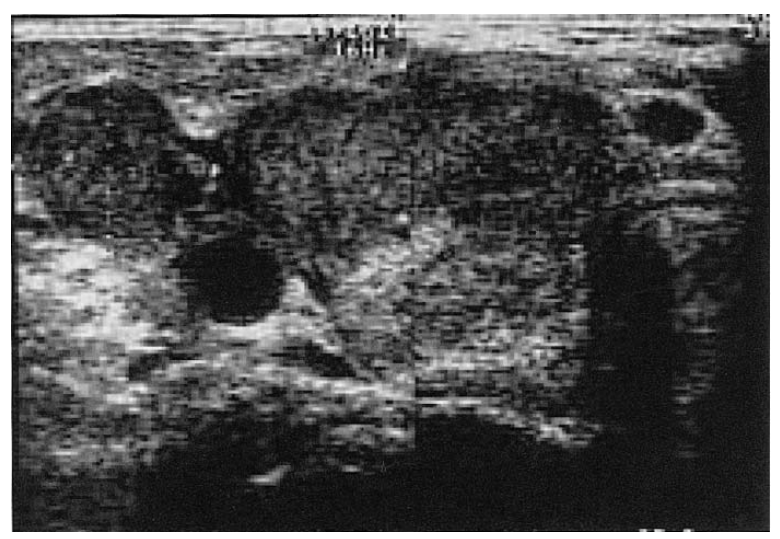

B

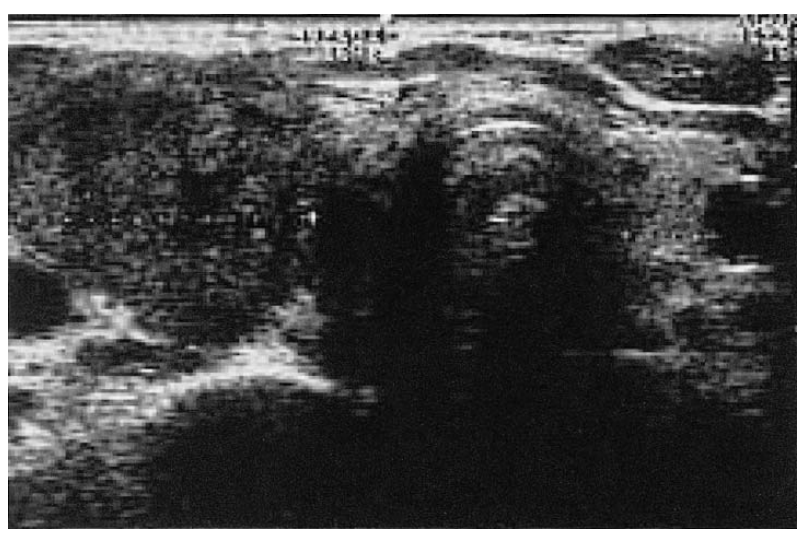

Fig. 1. Thyroid ultrasonography Thyroid ultrasonography showed a low echoic mass of $60.6 \times 37.3 \times 26.3 \mathrm{~mm}^{3}$ in the right thyroid lobe and bilateral cervical lymph node swellings (A, B). 
respectively. The right mass oppressed the common carotid artery and internal jugular vein and shifted the trachea to the left (Fig. 2A-C). It was cold on ${ }^{123} \mathrm{I}$ scintigraphy (Fig. 3A) and hot on early-(Fig. 3B) and delayed-(Fig. 3C) phases of ${ }^{201} \mathrm{Tl}$ scintigraphy. Whole body ${ }^{67} \mathrm{Ga}$ scintigraphy scan showed a strong hot accumulation in the area from the right thyroid lobe to the right lateral neck and a hot accumulation in the chest region (Fig. 3D). Multiple lung tumors were observed from the chest computed tomography (CT) scans. Cranial MR images showed no tumors. Based on the above findings, she was diagnosed as having an anaplastic thyroid carcinoma with metastatic lung tumors.

As she was elderly, she and her family refused to get chemotherapy or radiation treatments, or to undergo an operation for thyroid carcinoma. We therefore started percutaneous injection therapy of a mixed solution of lipiodol and ethanol $(\mathrm{v} / \mathrm{v}=1 / 1)$ (lip-PEIT). From August 26 to October 18, lip-PEIT was performed twice a week (13 times, total volume was $4.26 \mathrm{ml}$ ) against the primary thyroid carcinoma. TSH suppression therapy $[17,18]$ was also started because we suspected that her anaplastic carcinoma had transformed from a papillary carcinoma based on the elevated $\mathrm{Tg}$ levels in her blood and cytology. However, the thyroid carcinoma in her neck gradually enlarged and oppressed her trachea. Although bone ${ }^{99 \mathrm{~m}} \mathrm{Tc}$ scintigraphy showed hot spots at the neck of her right thigh bone, right frontal sinus and pelvic cavity, $\mathrm{x}$-ray and $\mathrm{CT}$ at each position showed no masses (Figure not shown). On a whole body ${ }^{67} \mathrm{Ga}$ scintigraphy scan on October 5, 2002, the hot accumulation from the right thyroid lobe to the right lateral neck was stronger than before and new metastatic lesions appeared in the lungs, liver and pelvic cavity.

Although the specific symptoms of hypercalcemia had not appeared, HHM was diagnosed because elevated serum levels of calcium $(2.72 \mathrm{mmol} / \mathrm{l}(10.9 \mathrm{mg} /$ dl)) and intact-PTHrP (3.2 pmol/l) (immunoradiometric assay (IRMA), Mitsubishi, Tokyo, Japan) and a decline of serum phosphate levels $(2.2 \mathrm{mg} / \mathrm{dl})$ were found on October 28, 2002 (Table 2). As the treatment for hypercalcemia, we selected bisphosphonate [1]. Hypercalcemia was reduced to $(2.12 \mathrm{mmol} / 1(8.5 \mathrm{mg} / \mathrm{dl}))$ by an intravenous injection of $30 \mathrm{mg}$ of pamidronate. After one week she died of an airway obstruction caused by the developing thyroid carcinoma.
Table 2. Laboratory data on Oct. 29, 2002

\begin{tabular}{ll}
\hline $\mathrm{Ca}$ & $2.72 \mathrm{mmol} / \mathrm{l}$ \\
$\mathrm{Pi}$ & $0.71 \mathrm{mmol} / \mathrm{l}$ \\
Albumin & $3 \mathrm{~g} / \mathrm{dl}$ \\
$\mathrm{Ca}^{2+}$ & $2.68 \mathrm{mEq} / \mathrm{l}(2.24-2.58)^{*}$ \\
Intact-PTH & $7 \mathrm{pg} / \mathrm{ml}(14-66)$ \\
Intact-PTHrP & $3.2 \mathrm{pmol} / 1(<1.1)$ \\
$1 \alpha-25(\mathrm{OH})_{2} \mathrm{VD}$ & $26 \mathrm{pg} / \mathrm{ml}(27.5-68.7)$ \\
Calcinonine & $23 \mathrm{pg} / \mathrm{ml}(15-86)$ \\
\hline
\end{tabular}

* Numbers in parentheses indicate the normal range.

\section{Autopsy}

Most of the tumor tissue in her neck consisted of anaplastic cancer nests, including carcinoma cells with large and atypical nuclei (Fig. 4A). A papillary pattern beside the trachea (Fig. 4B) and a squamoid pattern in its surroundings were observed. Osteoclast-like polymorphic and giant cells were spotted. Little necrosis was spotted in the tumor tissue. The invasion of carcinoma cells into lymphatic vessels and blood vessels was severe. Metastasis of the thyroid carcinoma was found in the lung, liver, spleen, small intestine, kidney and skin around the thoracic area.

Immunohistochemical staining of PTHrP using a $\times 1000$ dilution of anti-PTHrP(1-34) rabbit serum (Yanaihara Institute Inc., Shizuoka, Japan) showed that specimens of the resected tumors of the thyroid (Fig. 4C), liver, kidney, spleen, skin and small intestine (data not shown) were all positively stained to the same degree. The membrane and cytoplasm of the carcinoma cells were stained by anti-PTHrP(1-34) antisera.

Immunohistochemical staining of p53 using a $\times 100$ dilution of mouse p53 monoclonal antibody (DO-7, Novocastra Laboratories Ltd., Newcastle upon Tyne, UK) showed that species of the resected tumor of the thyroid were negatively stained.

\section{Discussion}

We have reported a rare case of a patient with anaplastic thyroid carcinoma with HHM diagnosed through an autopsy.

An anaplastic thyroid carcinoma is diagnosed using various images, such as ultrasonography, scintigraphy, and histopathological findings. In the present case, cytology of the thyroid tumor showed the suspected 
A

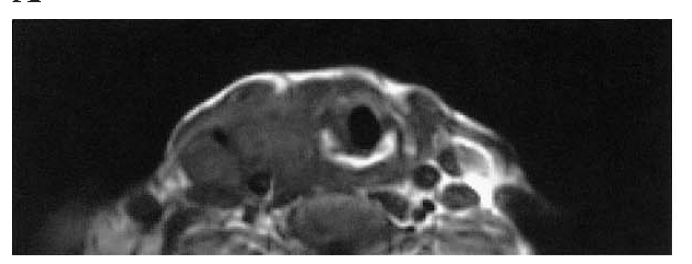

B
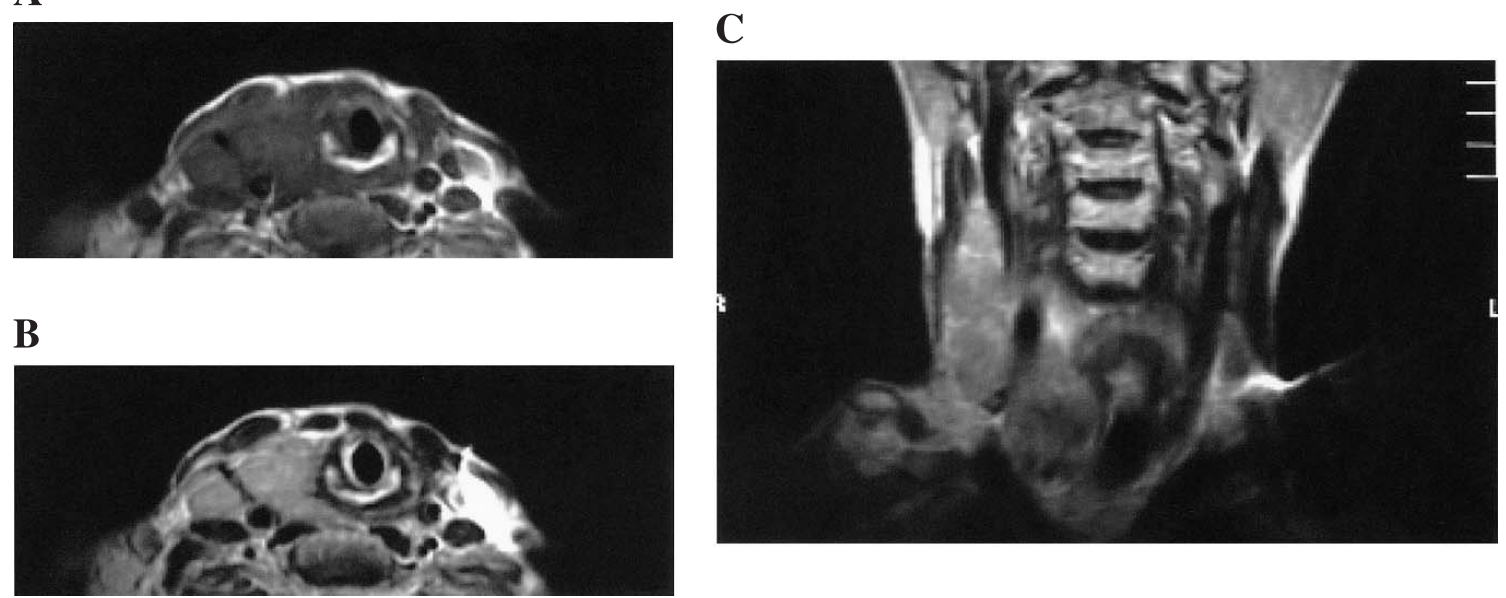

Fig. 2. Neck MR image

Her neck mass showed low- and high- intensity on T1- (A) and T2- (B, C) weighted MR images, respectively. The right mass oppressed the common carotid artery and internal jugular vein and shifted the trachea to the left.

$\mathbf{A}$

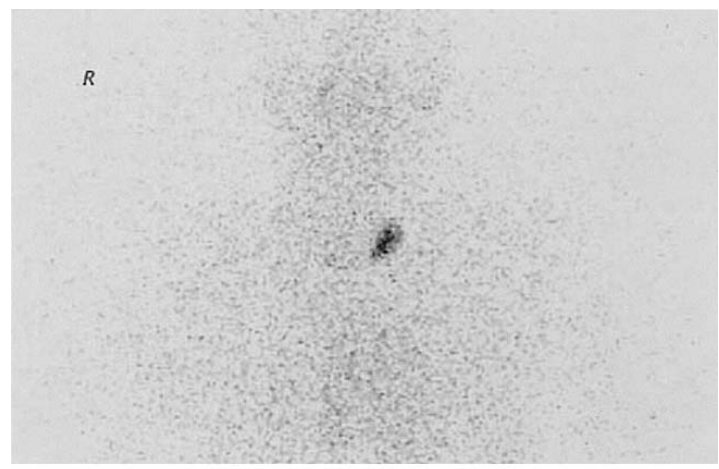

D

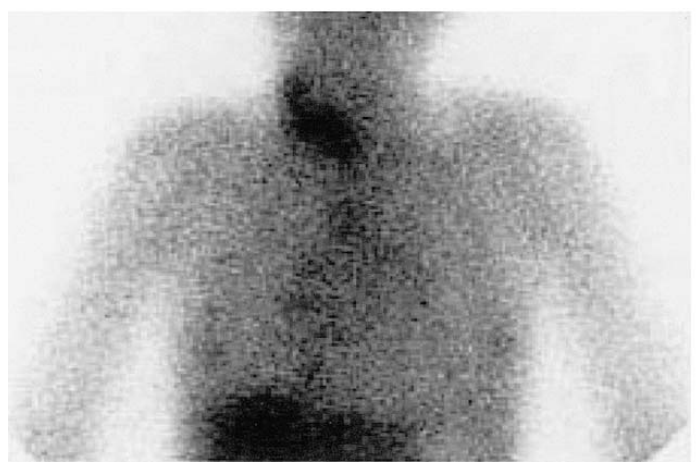

B

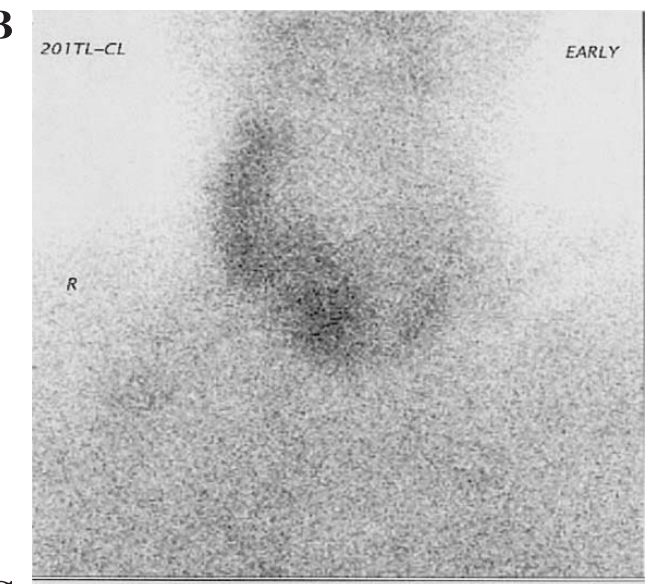

C

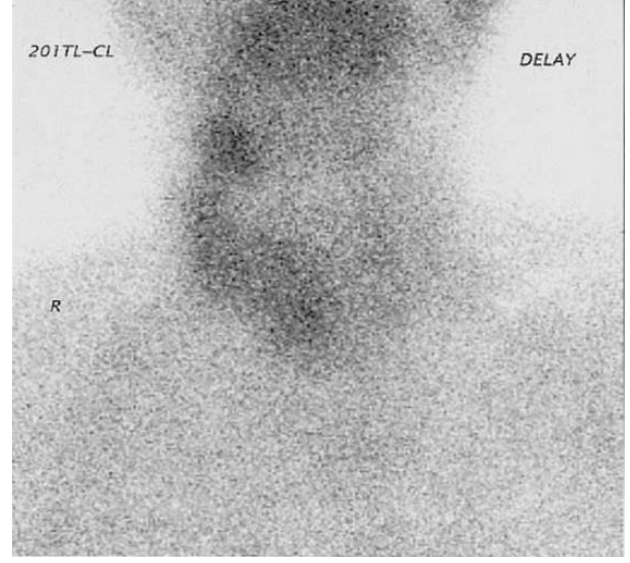

Fig. 3. Thyroid ${ }^{123} \mathrm{I}$ and ${ }^{201} \mathrm{Tl}$ scintigraphy and whole body ${ }^{67} \mathrm{Ga}$ scintigraphy scan

Her right neck mass was cold on ${ }^{123}$ I scintigraphy (A) and strongly hot in early phase ${ }^{201} \mathrm{Tl}$ scintigraphy (B) and decreased in washing-out in the delayed phase (C). Whole body ${ }^{67} \mathrm{Ga}$ scintigraphy scan showed a strong hot accumulation in the area from the left thyroid lobe to the lateral neck and hot accumulation in the chest region. Multiple lung tumors were observed from chest CT scans (D). 
A

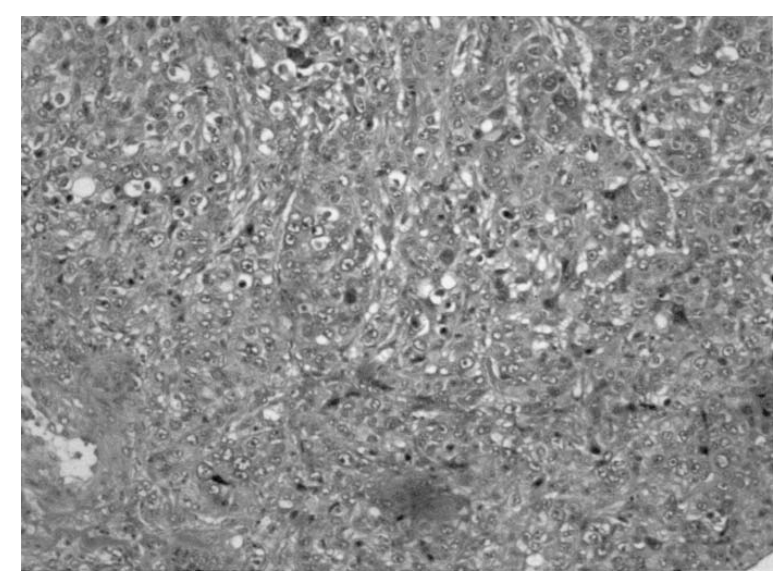

B

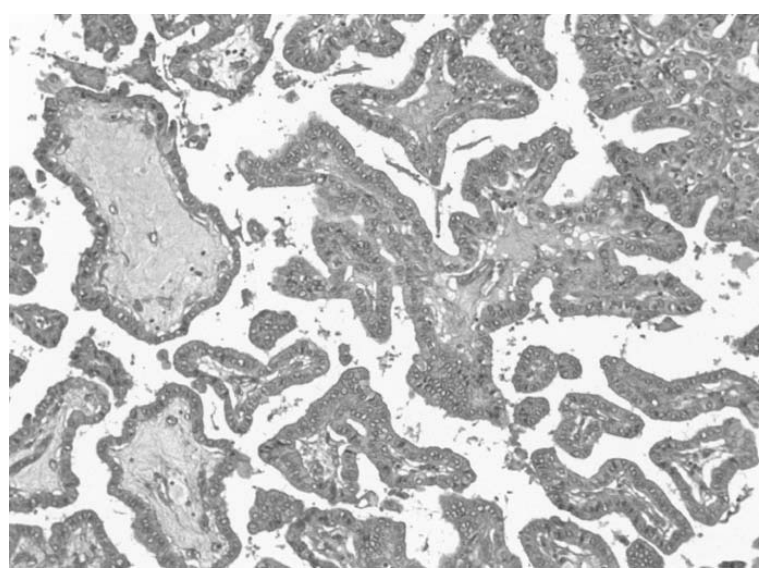

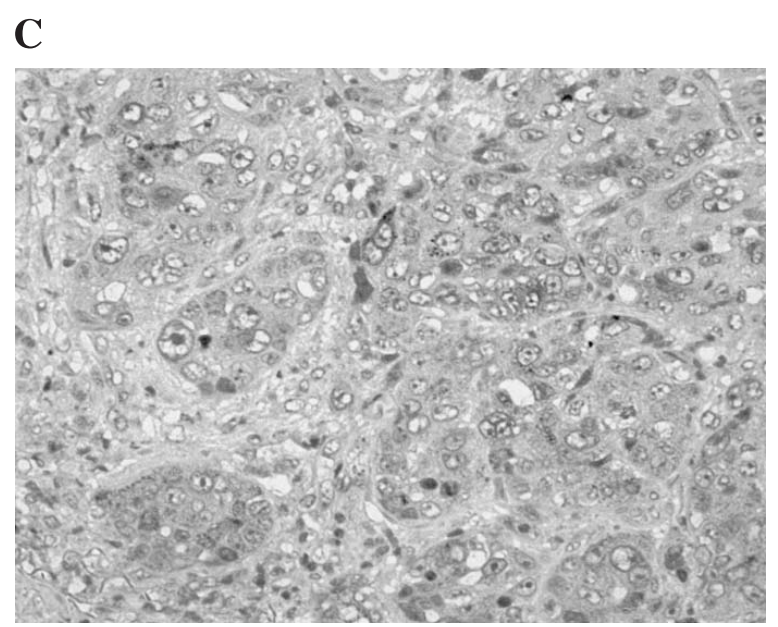

Fig. 4. Pathology of the thyroid carcinoma

Most of the tumor tissue in her neck consisted of anaplastic cancer nests, including carcinoma cells with large and atypical nuclei (A). A papillary pattern beside the trachea (B) and a squamoid pattern in its surroundings were observed. Osteoclastlike polymorphic and giant cells were spotted. The membrane and cytoplasm of the carcinoma cells were stained by antiPTHrP(1-34) antisera (C).

papillary carcinoma because intranuclear cytoplasmic inclusion was observed. However, some images showed anaplastic thyroid carcinoma. The pathological findings show that the thyroid tumor in the present case is mainly an anaplastic carcinoma associated with papillary carcinoma, suggesting the occurrence of an anaplastic transformation of a differentiated thyroid carcinoma [19-21].

Mutations of the p53 tumor suppressor gene play a major role in the development of many carcinomas, namely in the colon, breast and bladder [22-24]. The activation of the p53 gene is a late event associated with the most advanced stages of tumor progression [19, 21, 25-27]. Furthermore, overexpression of p53 plays a role as a prognostic factor of human thyroid carcinoma [28]. In literature, the incidence of p53 alterations in poorly differentiated and anaplastic carcinomas of the thyroid is reported to be $22-86 \%$ [19, 29-31]. However, the present case did not show such findings of p53 overexpression.

Our patient's thyroid carcinoma was inoperable, and she was elderly and she and her family refused to allow chemotherapy or radiation treatment, or to undergo an operation. Therefore, we chose local percutaneous injection therapy in the neck for her thyroid carcinoma.

PEIT has been established as being effective for thyroid cysts and functioning nodules [32, 33], as well as for thyroid carcinomas [34]. Furthermore, lip-PEIT was reported to be more effective than ethanol (PEIT) alone for solid thyroid tumors, including carcinomas 
Table 3. Some cases of patients with thyroid carcinoma and HHM

\begin{tabular}{ccccccccc}
\hline & Age & Sex & Histology & $\mathrm{Ca}(\mathrm{mmol} / \mathrm{l})$ & Intact-PTHrP & PTHrP-C & PTHrP $(1-87)$ & Authors and References \\
\hline 1 & 60 & F & PC & 2.79 & $138 \mathrm{pg} / \mathrm{ml}(<20)^{*}$ & & Ito et al. $(16)$ \\
2 & 58 & F & PC & $2.54-2.84$ & $284 \mathrm{pg} / \mathrm{ml}(<20)$ & & Ito et al. $(16)$ \\
3 & 67 & F & Anap. & 3.44 & & $164 \mathrm{pmol} / 1(13.8-55.3)^{*}$ & $4.02 \mathrm{pmol} / 1(<1.1)^{*}$ & Yazawa et al. $(15)$ \\
4 & 84 & F & Anap. & 2.72 & $3.2 \mathrm{pmol} / 1(<1.1)$ & Present case \\
\hline
\end{tabular}

Abbreviations: PC, papillary carcinoma; Anap., anaplastic carcinoma.

*Numbers in parentheses indicate the normal range.

[33]. However, the pathological findings in the present case suggest that lip-PEIT may not be effective for large thyroid carcinomas. Although the strategies to diagnose and treat the anaplastic carcinomas have been progressing, the prognosis of anaplastic thyroid carcinomas is still rather poor $[6-11,35,36]$.

As serum calcium levels were high and serum phosphate levels were low in the present case, primary hyperparathyroidism and HHM were initially suspected. Blood levels of intact-PTH and $1 \alpha-25(\mathrm{OH})_{2}$ VD were low, while PTHrP was high in sera. At this point in time, there were no signs of a metastatic bone tumor of the thyroid carcinoma. She was diagnosed as having HHM. Her laboratory data corresponded to the report that PTHrP has essentially the same actions as PTH through common receptors for PTH/PTHrP to elevate plasma calcium [37]. Based on the report that the receptor binding and activation domains of PTHrP are contained within the first 34 amino acids [38], we underwent an immunohistochemical staining of the primary thyroid carcinoma and metastatic tumors at several sites using anti-PTHrP(1-34) antisera. The findings of the immunohistochemical stain in the present case confirmed that thyroid carcinoma cells produced PTHrP. Pathological findings of the PTHrP staining of the primary and metastatic thyroid carcinoma suggest that HHM may involve the increasing of PTHrPproducing cells, but not the thyroid carcinoma's transforming to anaplastic carcinoma. To the best of our knowledge, HHM caused by a thyroid carcinoma has been reported in only 4 cases, including present case (Table 3).

Thus, we have reported a rare autopsy case of a patient with a PTHrP-producing anaplastic thyroid carcinoma.

\section{References}

1. Strewler GJ. Humoral manifestations of malignancy (2002) In: Larsen PR, Kronenberg HM, Melmed S, Polonsky KS (eds) Williams Textbook of Endocrinology, 10th ed., WB Saunders, Philadelphia, 1834-1856.

2. Bringhurst FR, Demay MB, Kronenberg HM. Hormones and disorders of mineral metabolism (2002) In: Larsen PR, Kronenberg HM, Melmed S, Polonsky KS (eds) Williams Textbook of Endocrinology, 10th ed., WB Saunders, Philadelphia, 1303-1371.

3. Moseley JM, Kubota M, Diefenbach-Jagger $H$, Wettenhall REH, Kemp BE, Suva LJ, Rodda CP, Ebeling PR, Hudson PJ, Zajac JD, Martin TJ (1987) Parathyroid hormone-related protein purified from a human lung cancer cell line. Proc Natl Acad Sci USA 84: 5048-5052.

4. Rankin W, Grill V, Martin TJ (1997) Parathyroid hormone-related protein and hypercalcemia. Cancer 80: 1564-1571.

5. Kitagawa W, Shimizu K, Akasu H, Tanaka S (2003)
Endocrine surgery. The ninth report: the latest data on and clinical characteristics of the epidemiology of thyroid carcinoma. J Nippon Med Sch 70: 57-61.

6. Obara T (1998) Anaplastic carcinoma. In: Takami H, Mori M (eds) A treatment manual for thyroid disease. Nankodo, Tokyo, 95-99.

7. Tsutsui K (1999) Thyroid anaplastic carcinoma: chemotherapy. Naibunpitsu Geka (Endocrine Surg) 16: 37-43 (in Japanese).

8. Ain KB, Egorin MJ, DeSimone PA (2000) Treatment of anaplastic thyroid carcinoma with paclitaxel: phase 2 trial using ninety-six-hour infusion. Collaborative Anaplastic Thyroid Cancer Health Intervention Trails (CATCHIT) Group. Thyroid 10: 587-594.

9. Kobayashi T, Asakawa H, Umeshita K, Takeda T, Maruyama H, Matsuzuka F, Monden M (1996) Treatment of 37 patients with anaplastic carcinoma of the thyroid. Head Neck 18: 36-41.

10. Tennvall J, Lundell G, Hallquist A, Wahlberg P, Wallin 
G, Tibblin S (1994) Combined doxorubicin, hyperfractionated radiotherapy, and surgery in anaplastic thyroid carcinoma. Report on two protocols. Swedish Anaplastic Thyroid Cancer Group. Cancer 74: 13481354.

11. Schlumberger MJ, Filetti S, Hay ID. Nontoxic goiter and thyroid neoplasia (2002) In: Larsen PR, Kronenberg HM, Melmed S, Polonsky KS (eds) Williams Textbook of Endocrinology, 10th ed., WB Saunders, Philadelphia, 457-490.

12. Sato S, Fujii Y, Kakiuchi T, Kasono K, Imamura H, Kondo Y, Mano H, Okabe T, Asano S, Takaku F, Tsushima T, Shizume K (1989) Paraneoplastic syndrome of hypercalcemia and leukocytosis caused by squamous carcinoma cells (T3M-1) producing parathyroid hormone-related protein, interleukin $1 \alpha$, and granulocyte colony-stimulating factor. Cancer Res 49: 47404746.

13. Yoshida A, Asaga T, Masuzawa C, Kawahara S (1993) Detection of cytokines in thyroid cancer cell lines by enzyme-linked immunosorbent assay. Naibunpitsu Geka (Endocrine Surg) 10: 9-12 (Abstract in English).

14. Enomoto T, Sugawa H, Inoue D, Miyamoto M, Kosugi S, Takahashi T, Kitamura N, Yamamoto I, Konishi J, Mori T, Imura H (1990) Establishment of a human undifferentiated thyroid cancer cell line producing several growth factors and cytokines. Cancer 65: 19711979.

15. Yazawa S, Toshimori H, Nakatsuru K, Katakami H, Takemura J, Matsukura S (1995) Thyroid anaplastic carcinoma producing granulocyte-colony-stimulating factor and parathyroid hormone-related protein. Internal Medicine 34: 584-588.

16. Ito Y, So T, Murayama M, Yasuda K, Miura K, Kitakami H, Matsukura S (1993) Two cases of thyroid papillary carcinoma with hypercalcemia and increased serum parathyroid hormone-related peptide-like immunoreactivity (PTHrP-LI). Horumon to Rinsho 41: 109-114 (in Japanese).

17. Nichols CW Jr, Lindsay S, Sheline GE, Chaikoff IL (1965) Induction of neoplasms in rat thyroid glands by x-irradiation of a single lobe. Arch Path 80: 177-183.

18. Mazzaferri EL (1987) Papillary thyroid carcinoma: factors influencing progress and current therapy. Semin Oncol 14: 315-332.

19. Farid NR, Shi YF, Zou MJ (1994) Molecular basis of thyroid cancer. Endocr Rev 15: 202-232.

20. Nishiyama RH, Dunn EL, Thompson NW (1972) Anaplastic spindle-cell and giant-cell tumors of the thyroid gland. Cancer 30: 113-127.

21. Ito T, Seyama T, Mizuno T, Tsuyama N, Hayashi Y, Dohi K, Namamura N, Akiyama M (1993) Genetic alterations in thyroid tumor progression: association with p53 gene mutations. Jpn J Cancer Res 84: 526531.
22. Silvestrini R, Benini E, Daidone MG (1993) p53 as an independent prognostic marker in lymph-node negative breast cancer patients. J Natl Cancer Inst 85: 965-970.

23. Baker SJ, Preisinger AC, Jessup JM, Paraskeva C, Markowitz S, Willson JK, Hamilton S, Vogelstein B (1990) p53 gene mutations occur in combination with $17 \mathrm{p}$ allelic deletions as late events in colorectal tumorigenesis. Cancer Res 50: 7717-7722.

24. Reznikoff CA, Kao C, Messing EM, Newton M, Swaminathan S (1993) A molecular genetic model of human bladder carcinogenesis. Sem Cancer Biol 4: $143-152$

25. Ito $T$, Seyama $T$, Mizuno $T$, Tsuyama N, Hayashi $T$, Hayashi Y, Dohi K, Nakamura N, Akiyama M (1992) Unique association of p53 mutation with undifferentiated but not differentiated carcinomas of the thyroid gland. Cancer Res 52: 1369-1371.

26. Nakamura T, Yana I, Kobayashi T, Shin E, Karakawa K, Fujita S, Miya A, Mori T, Nishisho I, Takai S (1992) p53 gene mutations associated with anaplastic transformation of human thyroid carcinomas. Jpn $J$ Cancer Res 83: 1293-1298.

27. Donghi R, Longoni A, Pilotti S, Michieli P, Della Porta G, Pierotti MA (1993) Gene p53 mutations are restricted to poorly differentiated and undifferentiated carcinomas of the thyroid gland. J Clin Invest 91: 17531760.

28. Dobashi Y, Sakamoto A, Sugimura H, Mernyei M, Mori M, Oyama T, Machinami R (1993) Overexpression of p53 as a possible prognostic factor in human thyroid carcinoma. Am J Surg Pathol 17: 375-381.

29. Lam KY, Lo CY, Chan KW, Wan KY (2000) Insular and anaplastic carcinoma of the thyroid. A 45-year comparative study at a single institution and a review of the significance of p53 and p21. Ann Surg 231: 329 338.

30. Moretti F, Nanni S, Pontecorvi A (2000) Molecular pathogenesis of thyroid nodules and cancer. Baillieres Best Pract Res Clin Endocrinol Metab 14: 517-539.

31. Soares P, Cameselle-Teijeiro J, Sobrinho-Simoes M (1994) Immunohistochemical detection of p53 in differentiated, poorly differentiated and undifferentiated carcinomas of the thyroid. Histopathology 24: 205210.

32. Kiyokawa T, Ohno Y, Iwai H, Harada T, Aoki N (2002) The study of percutaneous ethanol injection therapy (PEIT) for thyroid cyst and Plummer's disease. The examination on ultrasonography. Shinriou to Shinyaku 39: 772-773 (in Japanese).

33. Fukunari N (2002) Percutaneous ethanol injection therapy (PEIT) for thyroid diseases. Shinriou to Shinyaku 39: 767-769 (in Japanese).

34. Akasu H, Shimizu K, Kitagawa W, Naito Z, Kawanami O, Tanaka S (2002) Histological study of papillary thyroid carcinoma treated with percutaneous ethanol 
injection therapy. Pathol Int 52: 406-409.

35. Takano T, Amino N (2002) Cancer-specific mRNAs in thyroid carcinomas: detection, use, and their implication in thyroid carcinogenesis. Endocr J 49: 97-107.

36. Takano T, Hasegawa Y, Miyauchi A, Matsuzuka F, Yoshida H, Kuma K, Hayashi N, Nakamori S, Amino N (2002) Quantitative analysis of osteonectin mRNA in thyroid carcinomas. Endocr J 49: 511-516.

37. Jueppner H, Abou-Samra AB, Freeman M, Kong XF, Schipani E, Richards J, Kolakowski LF Jr, Hock J,
Potts JT Jr, Kronenberg HM, Segre GV (1991) A G protein-linked receptor for parathyroid hormone and parathyroid hormone-related peptide. Science 254: 1024-1026.

38. Abou-Samra AB, Uneno S, Jueppner H, Keutmann H, Potts JT Jr, Segre GV, Nussbaum SR (1989) Nonhomologous sequences of parathyroid hormone related peptide bind to a common receptor on ROS 17/2.8 cells. Endocrinology 125: 2215-2217. 